\title{
Ethanol, $\mathrm{Zn}^{2+}$ and insulin interact as progression factors to enhance DNA synthesis synergistically in the presence of $\mathrm{Ca}^{2+}$ and other cell cycle initiators in fibroblasts
}

\author{
Jin-Sheng HUANG, Qing-Bai SHE, Karan S. CRILLY and Zoltan KISS ${ }^{1}$ \\ The Hormel Institute, University of Minnesota, 801 16th Avenue NE, Austin, MN 55912, U.S.A.
}

In serum-starved NIH 3 T3 fibroblasts, ethanol $(30-80 \mathrm{mM})$ promoted the effects of insulin and insulin-like growth factor I (IGF-I) on DNA synthesis in a $\mathrm{Zn}^{2+}$-dependent manner. Ethanol and $\mathrm{Zn}^{2+}$ were most effective when added shortly before or after insulin, indicating that all these agents facilitated cell cycle progression. The synergistic effects of ethanol, $\mathrm{Zn}^{2+}$ and insulin (or IGF-I) on DNA synthesis required 1.1-2.3 $\mathrm{mM} \mathrm{Ca}^{2+}$, which seemed to act as the cell cycle initiator. When serum-starved cells were pretreated for $2 \mathrm{~h}$ with other cell cycle initiators such as $10 \%(\mathrm{v} / \mathrm{v})$ serum, $50 \mathrm{ng} / \mathrm{ml}$ platelet-derived growth factor or $2 \mathrm{ng} / \mathrm{ml}$ fibroblast growth factor, subsequent co-treatments with $60 \mathrm{mM}$ ethanol, $\mathrm{Zn}^{2+}$ and insulin for an $18 \mathrm{~h}$ period again synergistically increased DNA synthesis. Of the various signal transducing events examined, ethanol stimulated cellular uptake of ${ }^{45} \mathrm{Ca}$ and it enhanced the stimulatory effects of insulin on $\mathrm{p} 70$ S6 kinase activity in a $\mathrm{Zn}^{2+}$-dependent manner. In contrast, ethanol inhibited insulin-induced activating phosphorylation of p42/p44 mitogen-activated protein kinases; these inhibitory ethanol effects were prevented by $\mathrm{Zn}^{2+}$. The results show that, in NIH 3T3 fibroblasts, ethanol can promote cell cycle progression in the presence of a cell cycle initiator as well as $\mathrm{Zn}^{2+}$ and insulin (or IGF-I).

Key words: MAP kinase, mitogenesis, p70 S6 kinase.

\section{INTRODUCTION}

In many cellular systems in vitro, ethanol often inhibits growth factor-induced cell proliferation [1] or induces apoptosis [2,3]. Owing to similar inhibitory effects in vivo, alcohol abuse can cause various growth abnormalities in the growing embryo and fetus, leading to fetal alcohol syndrome $[4,5]$.

Heavy alcohol consumption can also promote the development of certain cancers induced by carcinogens [6-10]. Although ethanol can act, at least in part, as a solvent or as an inducer of microsomal enzymes that activate chemical carcinogens $[9,11]$, a more direct promoting effect of ethanol based on a stimulation of DNA synthesis and cell proliferation is also conceivable. This latter possibility is supported by findings that under specific conditions ethanol can indeed enhance mitogenesis. For example, a low $(0.1 \%, \mathrm{v} / \mathrm{v})$ concentration of ethanol was found to stimulate the preimplantation development of murine embryos accompanied by an increased implantation rate [12,13]. In other studies, ethanol stimulated the proliferation of cells in the neocortical subventricular zone in rat [14] as well as that of astrocytes in vitro [15]. Similarly, in the upper gastrointestinal tract and in the rectum, where alcohol exerts co-carcinogenic effects, alcohol intake resulted in mucosal hyperproliferation [16].

We have also reported that in serum-starved NIH 3T3 fibroblasts and several other cell types, $40-80 \mathrm{mM}$ ethanol can enhance the effects of insulin and insulin-like growth factor I (IGF-I) on DNA synthesis [17-19]. Furthermore, in human fibroblasts ethanol increased the stimulatory effect of $\mathrm{Ca}^{2+}$ on cell proliferation [20]. These findings were particularly interesting because a high expression of both insulin receptor [21,22] and IGF-I receptor $[23,24]$ promotes cell transformation and tumorigenesis, and high insulin levels increase the incidence of certain cancers [25]. Thus ethanol might be able to promote the effects of insulin and IGF-I on carcinogenesis by increasing growthfactor-stimulated mitogenesis. As a possible mechanism, stimulation of DNA synthesis by ethanol could stabilize mutageninduced structural changes in DNA, which, in turn, would increase the chances of cell transformation. Because of these potentially important implications, we are interested in determining the precise mechanism by which ethanol increases the effects of insulin and IGF-I on DNA synthesis.

In the present study our goals were to establish whether ethanol acts during the initiation or the progression phase of the cell cycle and how its actions are related to the effects of cell cycle initiators as well as $\mathrm{Zn}^{2+}$ and insulin. We report that in serumstarved NIH 3 T3 fibroblasts cultured in Dulbecco's modified Eagle's medium (DMEM) containing $1.8 \mathrm{mM} \mathrm{Ca}^{2+}$, ethanol functions as a $\mathrm{Zn}^{2+}$-dependent progression factor that promotes the effect of insulin, another progression factor. In agreement with previous observations that $\mathrm{Ca}^{2+}$ is essential for practically all stages of the cell cycle [26], we also found that extracellular $\mathrm{Ca}^{2+}$ is required both to facilitate the departure of cells from quiescence and to maintain cell cycle progression in the presence of ethanol, $\mathrm{Zn}^{2+}$ and insulin.

\section{EXPERIMENTAL}

\section{Materials}

Spectroscopic-grade ethanol was bought from Aldrich and was redistilled before use (in [17] this ethanol preparation is referred to as preparation ' 5 '); the first approx. $35 \%$ fraction of the distillate was discarded to eliminate possible traces of benzene. Insulin, IGF-I, fibroblast-derived growth factor (FGF) and platelet-derived growth factor (PDGF $\mathrm{B} / \mathrm{B}$ ) were purchased from Boehringer Mannheim; neomycin, $\mathrm{ZnCl}_{2}$ and $\mathrm{CaCl}_{2}$ were bought from Sigma; fura-2 acetoxymethyl ester was from Molecular Probes; the p42/p44 mitogen-activated protein (MAP)

Abbreviations used: DMEM, Dulbecco's modified Eagle's medium; FGF, fibroblast-derived growth factor; IGF-I, insulin-like growth factor I; MAP, mitogen-activated protein; PDGF, platelet-derived growth factor; PI-3K, phosphoinositide 3-kinase.

1 To whom correspondence should be addressed (e-mail kissx001@maroon.tc.umn.edu). 
kinase Western blot kit was purchased from New England Biolabs; the p70 S6 kinase immunoprecipitation kinase assay kit was bought from Upstate Biotechnology; p-TYR (PY20)agarose conjugate was from Santa Cruz Biotechnology; [methyl$\left.{ }^{3} \mathrm{H}\right]$ thymidine $(500 \mathrm{mCi} / \mathrm{mmol})$ and $\left[\gamma-{ }^{32} \mathrm{P}\right] \mathrm{ATP}(6000 \mathrm{Ci} / \mathrm{mmol})$ were purchased from Dupont $\mathrm{NEN}$; and all tissue culture reagents, including fetal bovine serum, were purchased from Gibco-BRL.

\section{Cell culture and preparation of stock solutions for $\mathrm{Ca}^{2+}$ and $\mathrm{Zn}^{2+}$}

Mouse embryo NIH 3T3 fibroblasts (A.T.C.C., Manassas, VA, U.S.A.) were cultured in DMEM containing $10 \%(\mathrm{v} / \mathrm{v})$ fetal bovine serum, as indicated earlier [17]; DMEM contains $1.8 \mathrm{mM}$ $\mathrm{Ca}^{2+}$. For these series of experiments the fibroblasts were cultured continuously for up to 40 passages. Because at higher concentrations $\mathrm{Ca}^{2+}$ is precipitated (in the form of insoluble Ca salts) in DMEM, stock solutions of $\mathrm{Ca}^{2+}$ were made up in water and $10 \mu 1$ aliquots were delivered to the cells. $\mathrm{ZnCl}_{2}$ stock solutions as well as all the other test solutions were prepared in DMEM.

\section{Labelling of cellular DNA with $\left[{ }^{3} \mathrm{H}\right]$ thymidine}

Fibroblasts were grown in 12-well tissue culture dishes to approx. $40 \%$ confluence in the presence of $10 \%(\mathrm{v} / \mathrm{v})$ serum, washed, incubated in serum-free DMEM for $24 \mathrm{~h}$, then washed again $3 \mathrm{~h}$ before treatments. Unless indicated otherwise, the cells (70-80\% confluent) were first treated (in serum-free medium; incubation volume $0.75 \mathrm{ml}$ ) with $40 \mu \mathrm{M} \mathrm{ZnCl}_{2}$ for $10 \mathrm{~min}$, then with ethanol for $10 \mathrm{~min}$, and finally with growth factors (in the presence of $\mathrm{Zn}^{2+}$ and ethanol) for $18 \mathrm{~h}$; [methyl $\left.-{ }^{3} \mathrm{H}\right]$ thymidine $(1 \mu \mathrm{Ci}$ per well) was present during the last $60 \mathrm{~min}$ of treatment. The cells were washed twice with PBS, then four times with $5 \%(\mathrm{w} / \mathrm{v})$ trichloroacetic acid, and finally twice with ethanol. The acidinsoluble material was redissolved in $0.3 \mathrm{M} \mathrm{NaOH}$ and an aliquot was taken to measure DNA-associated ${ }^{3} \mathrm{H}$ activity in a liquid-scintillation counter. Cell numbers in approx. $80 \%$ confluent cultures were approx. $(1.5-1.7) \times 10^{5}$ per well.

\section{Western blot analysis of ethanol effects on the phosphorylation of MAP kinases}

Serum-starved (24 h) NIH 3T3 cells, grown in $35 \mathrm{~mm}$ diameter dishes to $70-80 \%$ confluence, were first incubated with $40 \mu \mathrm{M}$ $\mathrm{Zn}^{2+}$ for $2 \mathrm{~min}$, then treated with ethanol for $2 \mathrm{~min}$ and finally with insulin for $5 \mathrm{~min}$. Samples for immunoblot analysis were prepared as described previously [17,27]. Phospho-specific MAP kinase antibodies (New England Biolabs), recognizing the Tyr204 phosphorylation site in the p42 and p44 MAP kinases, were used to detect the phosphorylated (activated) forms. The Western immunoblotting protocol was performed in accordance with the instructions of the manufacturer. The relative changes in the intensity of phosphorylation were determined by a Storm 840 PhosphorImager (Molecular Dynamics).

\section{Assay of p70 S6 kinase activity}

The activity of p70 S6 kinase, immunoprecipitated from control and treated NIH $3 \mathrm{~T} 3$ cell extracts, was determined by using the substrate peptide AKRRRLSSLRA (Upstate Biotechnology) as described earlier [27].

\section{Assay of phosphoinositide 3-kinase (PI-3K) activity}

PI-3K activity, immunoprecipitated with PY20-agarose conjugate from control and treated NIH 3T3 cell extracts, was determined as described previously [28].

\section{Determination of cellular uptake of ${ }^{45} \mathrm{Ca}$}

Serum-starved $(24 \mathrm{~h})$ subconfluent NIH 3 T3 cells were preincubated with $40 \mu \mathrm{M} \mathrm{Zn}^{2+}$ for $2 \mathrm{~min}$, followed by incubations in serum-free medium $(600 \mu \mathrm{l})$ for up to $3 \mathrm{~h}$ in the presence of ${ }^{45} \mathrm{Ca}$ $(5 \mu \mathrm{Ci})$. Cells were washed twice with $4 \mathrm{ml}$ of medium within $40 \mathrm{~s}$ followed by the addition of $1.5 \mathrm{ml}$ of ice-cold methanol/water $(4: 1, \mathrm{v} / \mathrm{v})$ mixture to the wells to extract ${ }^{45} \mathrm{Ca}$. The whole volume plus a $0.5 \mathrm{ml}$ methanol/water wash were combined to measure radioactivity. Blank values (0 min incubation with ${ }^{45} \mathrm{Ca}$ ) were approx. $8-10 \%$ of the value obtained after incubation for $30 \mathrm{~min}$ in the absence of $\mathrm{Zn}^{2+}$.

\section{RESULTS}

Dependence of the synergistic actions of ethanol, $\mathrm{Zn}^{2+}$ and insulin on DNA synthesis on the timing of ethanol addition

In serum-starved NIH $3 \mathrm{~T} 3$ fibroblasts incubated in the presence of $40 \mu \mathrm{M} \mathrm{Zn}^{2+}$, insulin alone stimulated DNA synthesis approx. 8 -fold after treatment for $18 \mathrm{~h}$. Addition of $20-80 \mathrm{mM}$ ethanol $3 \mathrm{~h}$ before insulin had minimal effects on DNA synthesis (Figure 1). In contrast, $50-80 \mathrm{mM}$ ethanol enhanced the effect of insulin 8.8-14-fold when added $10 \mathrm{~min}$ before insulin (Figure 1). Ethanol was the most effective when added $30 \mathrm{~min}$ after insulin; in this case, even $30 \mathrm{mM}$ ethanol had a well detectable (approx. 2-fold) potentiating effect (Figure 1). Finally, $50-80 \mathrm{mM}$ ethanol produced only small potentiating effects when added 60 min after insulin (Figure 1).

In the above and subsequent experiments, ethanol was added to cells only once, without sealing the wells. Under this condition, the concentration of ethanol decreases by approx. $50 \%$ during a $4 \mathrm{~h}$ incubation period [12]. When the above experiments were repeated by using incubators that contained 2 litres of 60 or $80 \mathrm{mM}$ ethanol in open trays (an established procedure to minimize the evaporation of ethanol from the wells), the direct

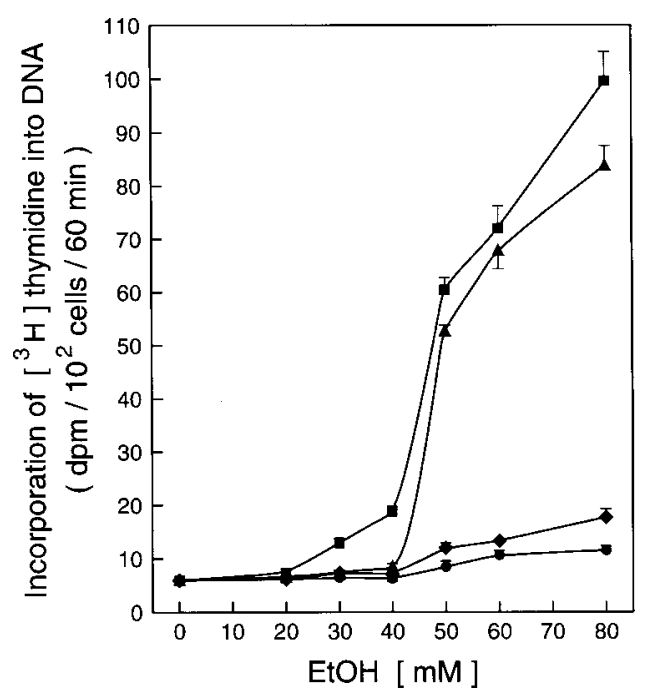

Figure $1 \mathrm{Zn}^{2+}$-dependent potentiating effects of ethanol on insulinstimulated DNA synthesis

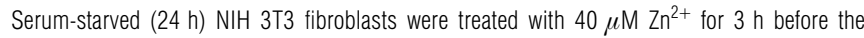
addition of $500 \mathrm{nM}$ insulin. Cells were treated with insulin for $18 \mathrm{~h}$ in the presence of $0-80 \mathrm{mM}$ ethanol (EtOH) as indicated; ethanol was added $3 \mathrm{~h}$ before insulin $(\mathbf{O}), 10 \mathrm{~min}$ before insulin $(\boldsymbol{\Delta}), 30 \mathrm{~min}$ after insulin $(\boldsymbol{\square})$ or $60 \mathrm{~min}$ after insulin ( ). Points are means \pm S.D. for six incubations in a single experiment representative of two similar experiments performed in triplicate. 


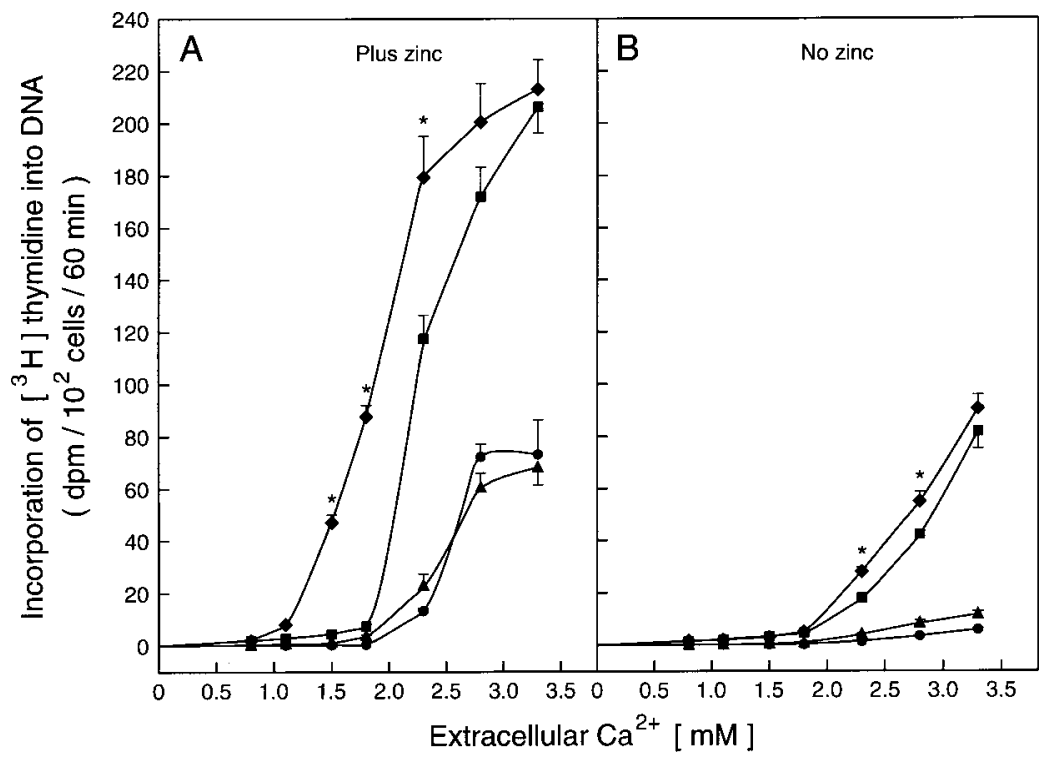

Figure $2 \mathrm{Ca}^{2+}$ dependence of the combined synergistic effects of ethanol, $\mathrm{Zn}^{2+}$ and insulin on DNA synthesis

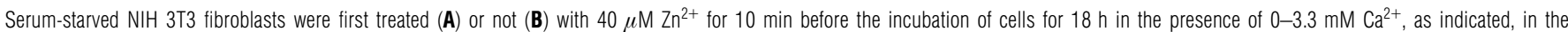
absence $(\mathbf{O})$ or presence of $60 \mathrm{mM}$ ethanol $(\mathbf{A}), 500 \mathrm{nM}$ insulin $(\boldsymbol{\square})$ or ethanol plus insulin $(\boldsymbol{})$; ethanol was added 10 min before insulin. Points are means \pm S.E.M. for three experiments, each performed in triplicate within $24 \mathrm{~h}$ with the same passage of cells. *Significantly $(P<0.01)$ different from the corresponding effects of insulin without ethanol.

addition of $60-80 \mathrm{mM}$ ethanol to the cells $10 \mathrm{~min}$ before insulin actually inhibited (by 16-24\%) the mitogenic effect of insulin on DNA synthesis (results not shown). It is therefore clear that in NIH 3 T3 fibroblasts only limited exposure to a relatively low concentration of ethanol is capable of increasing the effect of insulin on DNA synthesis.

The large potentiating effects of ethanol on $\left[{ }^{3} \mathrm{H}\right]$ thymidine incorporation into DNA were observed only after incubations for $16-20 \mathrm{~h}$, i.e. when the cells were in the S-phase and very little ethanol was actually present in the medium. In addition, 60-80 mM ethanol had no effect on the cellular uptake of $\left[{ }^{3} \mathrm{H}\right]$ thymidine over a $12 \mathrm{~h}$ incubation period, excluding the possibility that the labelling of DNA reflected ethanol-stimulated cellular uptake of radiolabelled thymidine. The potentiating effects of ethanol, but not the effect of insulin alone, required $\mathrm{Zn}^{2+}$; under the conditions used, $40 \mu \mathrm{M} \mathrm{Zn}^{2+}$ had optimal effects.

\section{Role of $\mathrm{Ca}^{2+}$ as a cell cycle initiator}

Because insulin is known to be a cell cycle progression factor, and the above results indicated that ethanol also acts in the progression phase, the incubation system had to contain an initiator of the cell cycle, which acted together with the progression factors insulin, ethanol and $\mathrm{Zn}^{2+}$ to guide the cells into $\mathrm{S}$-phase. Because $\mathrm{Ca}^{2+}$ is known to be required for practically all stages of the cell cycle, including entry from serum-starvationimposed quiescence (reviewed in [26]), we hypothesized that in our serum-free system $\mathrm{Ca}^{2+}$ was the cell cycle initiator. In agreement with this possibility, at $0.8-1.1 \mathrm{mM} \mathrm{Ca}^{2+}$ ethanol, insulin and $\mathrm{Zn}^{2+}$ alone or in combination had practically no effect on DNA synthesis (Figure 2A). In the presence of $\mathrm{Zn}^{2+}$, ethanol and insulin had detectable effects at $1.5 \mathrm{mM} \mathrm{Ca}^{2+}$ and they exerted nearly maximal synergistic effects at $1.8 \mathrm{mM} \mathrm{Ca}^{2+}$ (Figure 2A). Higher (2.3-3.3 mM) concentrations of $\mathrm{Ca}^{2+}$ greatly enhanced the mitogenic effect of insulin even in the absence of ethanol, although at $2.3 \mathrm{mM} \mathrm{Ca}^{2+}$ the potentiating effect of ethanol was still significant (Figure 2A). Insulin and ethanol in combination had much less effects on DNA synthesis in the absence of $\mathrm{Zn}^{2+}$ (Figure 2B). Finally, it is interesting to note that $\mathrm{Zn}^{2+}$ increased the effects of $2.8-3.3 \mathrm{mM} \mathrm{Ca}^{2+}$ on DNA synthesis, even in the absence of insulin (Figure 2A).

\section{Ethanol, $\mathrm{Zn}^{2+}$ and insulin can also synergistically enhance the effects of serum, PDGF and FGF}

We next tested whether ethanol, $\mathrm{Zn}^{2+}$ and insulin are also capable of enhancing the effects of other well-known cell cycle initiators such as serum, FGF and PDGF. As shown in Table 1, pretreatment of serum-starved fibroblasts with each agent for $2 \mathrm{~h}$ in the presence of $1.8 \mathrm{mM} \mathrm{Ca}^{2+}$ resulted in modest increases in DNA synthesis; these were considerably enhanced by ethanol in the presence of $\mathrm{Zn}^{2+}$ (but not in its absence), particularly if insulin was also present. The addition of $0.7 \mathrm{mM}$ EGTA, a $\mathrm{Ca}^{2+}$ chelator, abolished the synergistic $\mathrm{Zn}^{2+}$-dependent effects of ethanol and insulin in the absence of growth factors, whereas EGTA had smaller inhibitory effects when the cells were pretreated with serum, FGF or PDGF for $2 \mathrm{~h}$ (Table 1). It therefore seems that ethanol and insulin can synergistically increase, in a $\mathrm{Zn}^{2+}$-dependent manner, DNA synthesis in combination with various cell cycle initiators, although the magnitude of effects is still influenced by the concentration of $\mathrm{Ca}^{2+}$. We should note that full serum and a maximally effective concentration $(20 \mathrm{ng} / \mathrm{ml})$ of FGF can also act as progression factors; accordingly, if they were present during the entire $(18 \mathrm{~h})$ treatment period, ethanol and insulin had no additional effects, whereas the effects of PDGF and $2 \mathrm{ng} / \mathrm{ml}$ FGF were still enhanced 2-2.6-fold by ethanol plus insulin (results not shown).

\section{Effect of ethanol on $\mathrm{Ca}^{2+}$ mobilization and ${ }^{45} \mathrm{Ca}$ uptake}

By using fura-2 acetoxymethyl ester $[29,30]$ to detect changes in the concentration of cytoplasmic $\mathrm{Ca}^{2+}$ in serum-starved NIH 3T3 


\section{Table $1 \mathrm{Zn}^{2+}$-dependent stimulation of DNA synthesis by ethanol and insulin after pretreatments with serum and growth factors}

Serum-starved (24 h) NIH 3 T3 fibroblasts were first treated for $2 \mathrm{~h}$ with $10 \%$ (V/v) serum, $2 \mathrm{ng} / \mathrm{ml} \mathrm{FGF} \mathrm{or} 50 \mathrm{ng} / \mathrm{ml} \mathrm{PDGF}$, as indicated. After being washed, cells were treated for $10 \mathrm{~min}$ with

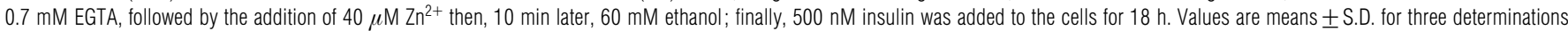
in a single experiment representative of three similar experiments

\begin{tabular}{|c|c|c|c|c|c|}
\hline \multirow[b]{2}{*}{ Condition } & \multirow[b]{2}{*}{ Growth factor } & \multicolumn{4}{|c|}{$\begin{array}{l}\text { Incorporation of }\left[{ }^{3} \mathrm{H}\right] \text { thymidine into } \\
\text { DNA (d.p.m. } / 60 \text { min per } 10^{5} \text { cells) }\end{array}$} \\
\hline & & None & Insulin & Ethanol & Insulin + ethanol \\
\hline \multirow[t]{4}{*}{ No $\mathrm{Zn}^{2+}$} & None & $529 \pm 54$ & $5679 \pm 306$ & $513 \pm 61$ & $5043 \pm 297$ \\
\hline & Serum & $12500 \pm 1230$ & $73610 \pm 8140$ & $14581 \pm 1250$ & $102380 \pm 6040$ \\
\hline & FGF & $10410 \pm 850$ & $44550 \pm 4970$ & $11510 \pm 1070$ & $60820 \pm 4170$ \\
\hline & PDGF & $9880+610$ & $49230+5780$ & $11300+950$ & $66820+5760$ \\
\hline \multirow[t]{4}{*}{$\mathrm{Zn}^{2+}$} & None & $1380 \pm 150$ & $11470 \pm 990$ & $5710 \pm 560$ & $87360 \pm 4990$ \\
\hline & Serum & $14850 \pm 1830$ & $77530 \pm 9260$ & $73640 \pm 6260$ & $226810 \pm 14080$ \\
\hline & FGF & $12410 \pm 1650$ & $50570 \pm 8090$ & $32800 \pm 4250$ & $148970 \pm 11860$ \\
\hline & PDGF & $11080 \pm 2130$ & $54170 \pm 3860$ & $29310 \pm 1510$ & $166710 \pm 22404$ \\
\hline \multirow[t]{4}{*}{$\mathrm{EGTA}+\mathrm{Zn}^{2+}$} & None & $506 \pm 120$ & $6420 \pm 400$ & $598 \pm 145$ & $6810 \pm 1040$ \\
\hline & Serum & $7590 \pm 930$ & $38750 \pm 2810$ & $21310 \pm 2650$ & $89360 \pm 10550$ \\
\hline & FGF & $6070 \pm 1140$ & $31810 \pm 2930$ & $16690 \pm 1410$ & $66810 \pm 6010$ \\
\hline & PDGF & $4150 \pm 600$ & $24180 \pm 1720$ & $18960 \pm 1940$ & $78440 \pm 2520$ \\
\hline
\end{tabular}

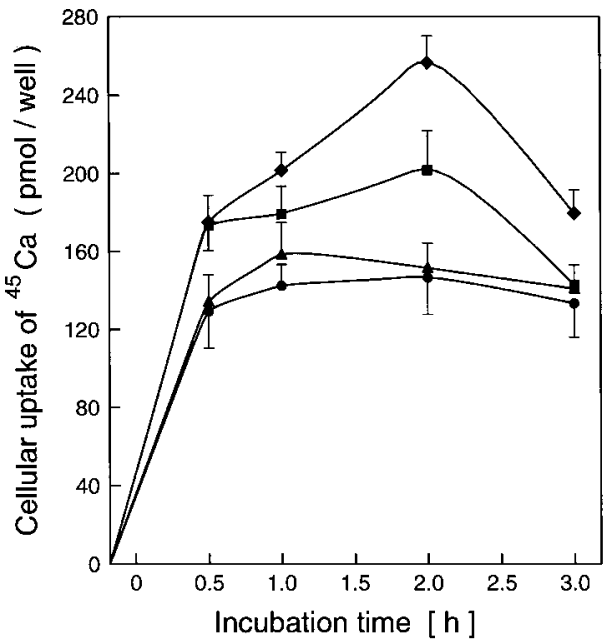

Figure 3 Effects of ethanol on ${ }^{45} \mathrm{Ca}$ uptake in NIH $3 \mathrm{~T} 3$ fibroblasts

Serum-starved subconfluent NIH 3T3 fibroblast cultures were incubated in $1.8 \mathrm{mM} \mathrm{Ca}^{2+}$. containing medium for up to $3 \mathrm{~h}$, as indicated, with ${ }^{45} \mathrm{Ca}$ in the absence $(\mathbf{O})$ or presence of $40 \mu \mathrm{M} \mathrm{Zn} n^{2+}(\boldsymbol{\Delta}), 60 \mathrm{mM}$ ethanol $(\boldsymbol{\square})$ or $\mathrm{Zn}^{2+}$ plus ethanol $(\bullet)$. Points are means \pm S.D. for four incubations in a single experiment. Similar effects of ethanol were seen in three other experiments, each performed in duplicate.

fibroblasts, we found that ethanol had no significant effect (results not shown) over a 10 min observation period. In contrast, in serum-starved subconfluent fibroblasts, $60 \mathrm{mM}$ ethanol enhanced the cellular uptake of ${ }^{45} \mathrm{Ca}$ after incubation for $0.5-2 \mathrm{~h}$ (Figure 3). Whereas $\mathrm{Zn}^{2+}(40 \mu \mathrm{M})$ alone had no effect, it seemed to enhance slightly the stimulatory effect of ethanol after incubations for 2 and $3 \mathrm{~h}$ (Figure 3 ). These results indicated that under the above conditions ethanol has relatively long-term stimulatory effects on $\mathrm{Ca}^{2+}$ uptake that can be enhanced by $\mathrm{Zn}^{2+}$. We should note here that ethanol was less effective in stimulating ${ }^{45} \mathrm{Ca}$ uptake in confluent cell cultures (results not shown); the reason for this is unknown.

\section{Possible role of $\mathrm{Ca}^{2+}$ receptors in the mediation of effects of $\mathrm{Ca}^{2+}$ and ethanol on DNA synthesis}

$\mathrm{Ca}^{2+}$ could act on DNA synthesis via $\mathrm{Ca}^{2+}$ receptors, which are expressed in several cell types [31-33] including Rat-1 fibroblasts [34]. To examine this possibility, we first determined whether neomycin, an agonist of $\mathrm{Ca}^{2+}$ receptors [32], could augment the potentiating effects of ethanol and $\mathrm{Zn}^{2+}$ on DNA synthesis. In the presence of $1.8 \mathrm{mM} \mathrm{Ca}^{2+}$ and $40 \mu \mathrm{M} \mathrm{Zn}{ }^{2+}$, neomycin $(0.5-1 \mathrm{mM})$ significantly enhanced the stimulatory effects of ethanol on DNA synthesis, in both the absence and the presence of insulin (Figure 4A), whereas neomycin did not increase the effect of insulin alone (Figure 4A). In the absence of $\mathrm{Zn}^{2+}$, neomycin had smaller effects on DNA synthesis induced by ethanol plus insulin and it did not modify the individual effects of ethanol and insulin (Figure 4B). EGTA (1 mM) completely blocked not only the effects of ethanol and insulin but also that of neomycin (results not shown). It should be added here that in the $0.5-1 \mathrm{mM}$ range neomycin had no cytotoxic effects but at $2 \mathrm{mM}$ it slightly increased the number of dead cells.

In contrast with neomycin, gadolinium $(0.2-1 \mathrm{mM})$, another agonist of the $\mathrm{Ca}^{2+}$ receptor, did not modify the effects of ethanol and insulin on DNA synthesis, which raised concerns about the role of $\mathrm{Ca}^{2+}$ receptors. We therefore next examined the effects of ethanol and insulin on DNA synthesis in Rat-1 fibroblasts, which express $\mathrm{Ca}^{2+}$ receptors [34]. In this system, insulin enhanced DNA synthesis approx. 3-fold; however, $60 \mathrm{mM}$ ethanol had a much smaller (approx. 1.4-fold) potentiating effect than in NIH $3 \mathrm{~T} 3$ fibroblasts. Finally, we developed four different NIH 3T3 clones highly overexpressing human $\mathrm{Ca}^{2+}$ receptors [32]. Although this work will be reported elsewhere with a focus on $\mathrm{Ca}^{2+}$ regulation, we note here that the overexpression of $\mathrm{Ca}^{2+}$ receptors did not increase the effects of ethanol, $\mathrm{Zn}^{2+}$ and insulin on DNA synthesis at any concentration (1.1-2.8 mM) of extracellular $\mathrm{Ca}^{2+}$ examined (results not shown).

Each DNA synthesis experiment performed with insulin was repeated with IGF-I. In each case, $50 \mathrm{ng} / \mathrm{ml}$ IGF-I mimicked the effects of $500 \mathrm{nM}$ insulin. We therefore assume that insulin and IGF-I are equivalent in their interactions with ethanol, $\mathrm{Zn}^{2+}$ and $\mathrm{Ca}^{2+}$ on DNA synthesis. 


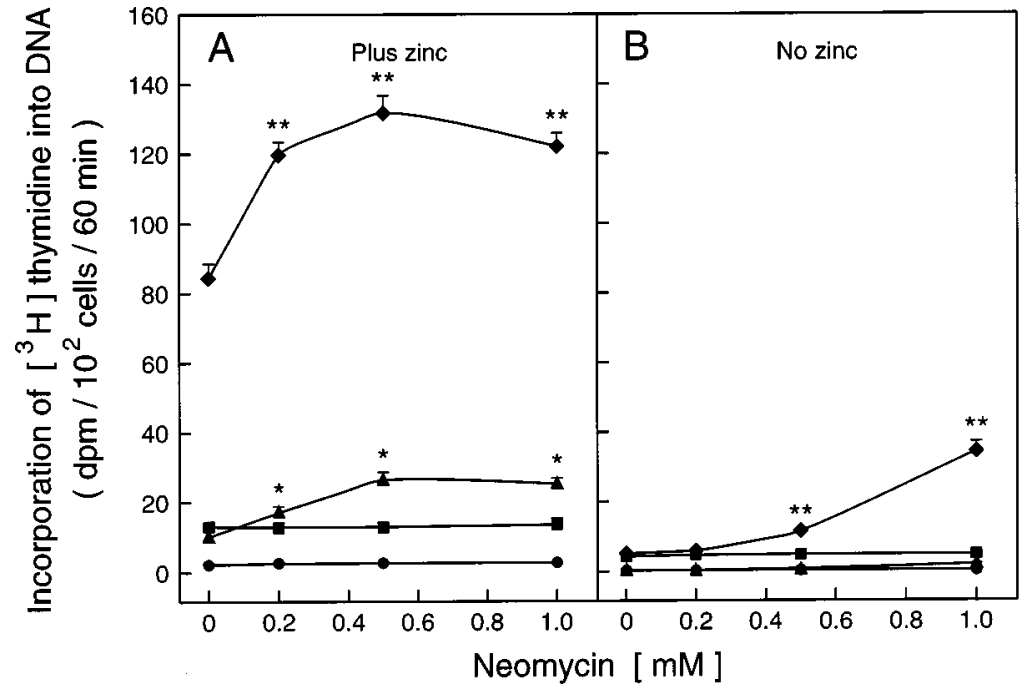

Figure 4 Effects of neomycin on ethanol-stimulated and insulin-stimulated DNA synthesis

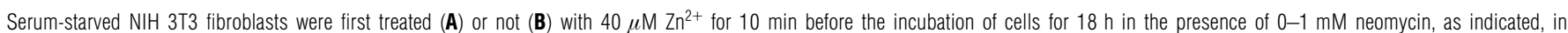
the absence $(\mathbf{O})$ or presence of $60 \mathrm{mM}$ ethanol $(\boldsymbol{\Delta}), 500 \mathrm{nM}$ insulin $(\boldsymbol{\square})$ or ethanol plus insulin $(\bullet)$. Points are means \pm S.E.M. for three experiments, each performed in triplicate. ${ }^{*}$, ${ }^{* \star}$ Significantly $(P<0.01)$ different from the corresponding value obtained with ethanol alone $\left(^{*}\right)$ or with ethanol plus insulin $\left(^{(*)}\right.$.

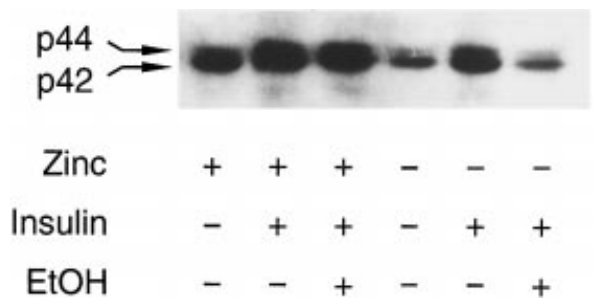

Figure 5 Western blot analysis of the effects of insulin, ethanol and $\mathrm{Zn}^{2+}$ on the phosphorylation of p42/p44 MAP kinases in NIH 3T3 fibroblasts

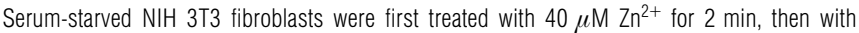
$60 \mathrm{mM}$ ethanol (EtOH) for $2 \mathrm{~min}$, and finally with $500 \mathrm{nM}$ insulin for $5 \mathrm{~min}$, as indicated. The tyrosine-phosphorylated (activated) forms of p42/p44 MAP kinases were analysed by immunoblotting as described in the Experimental section. The experiment was repeated twice with similar results.

\section{Effects of ethanol, $\mathrm{Zn}^{2+}$ and insulin on signal transduction}

The activation of p42/p44 MAP kinases (also called extracellular signal-regulated kinases, or ERKs) is required for fibroblast growth [35]. However, we found previously that in NIH 3T3 fibroblasts the stimulatory effects of insulin on the phosphorylation (activation) of these enzymes after $10 \mathrm{~min}$ of treatment were actually inhibited by ethanol [17]. In that study, though, $\mathrm{Zn}^{2+}$ was not added to the incubation medium, and earlier time points were not examined. Because the potentiating effect of ethanol on insulin-induced DNA synthesis depends on $\mathrm{Zn}^{2+}$, we now re-examined the combined effects of insulin and ethanol on the activating phosphorylation of MAP kinases in the presence of $\mathrm{Zn}^{2+}$ at an earlier (5 min) time point. As shown in Figure 5, in the presence of $\mathrm{Zn}^{2+}$, insulin clearly (approx. 2.1-2.3-fold) stimulated the phosphorylation of p42/p44 MAP kinases; ethanol did not modify these insulin effects. In contrast, in the absence of $\mathrm{Zn}^{2+}$, ethanol visibly inhibited the smaller stimulatory effects of insulin. Accordingly, one function of $\mathrm{Zn}^{2+}$ might be to prevent the inhibitory effect of ethanol on insulin-induced MAP kinase phosphorylation.

In addition to MAP kinases, insulin also activates p70 S6 kinase, a serine/threonine kinase that phosphorylates $40 \mathrm{~S}$ ribosomal protein $\mathrm{S} 6$ in response to stimulation with mitogen [36]. Because activation of this enzyme seems to be obligatory for cell cycle progression through $G_{1}$ and $S$-phase [37,38], insulinstimulated p70 S6 kinase was considered to be a target for the action of ethanol. Previously, treatment with ethanol for $10 \mathrm{~min}$ was found to enhance the effect of insulin moderately [18]. Now we extended these studies to examine other time points as well as the role of $\mathrm{Zn}^{2+}$. As shown in Figure 6(A), after $5 \mathrm{~min}$ of treatment in the presence of $\mathrm{Zn}^{2+}$, insulin reached almost its maximal effect on p70 S6 kinase activation; ethanol enhanced this further by approx. $48 \%$. The relative potentiating effect of ethanol became smaller ( $27 \%$ increase) after 10 min of treatment; it was negligible after $30 \mathrm{~min}$ (Figure 6A). Whereas $\mathrm{Zn}^{2+}$ did not cause a marked change in the effect of insulin alone, in its absence ethanol had no detectable potentiating effects (Figure 6B). It should be added that ethanol alone also approximately doubled the activity of p70 S6 kinase at each time point examined; these effects of ethanol did not seem to require $\mathrm{Zn}^{2+}$ (Figure 6).

The activation of p70 S6 kinase by insulin involves PI-3K [36], although other mechanisms might also contribute. Previously, we reported that, after $10 \mathrm{~min}$ of incubation, ethanol enhanced only slightly the effect of insulin on PI-3K activity and that the PI-3K inhibitor wortmannin barely inhibited the combined effects of insulin and ethanol on DNA synthesis [18]. In the present study, $60 \mathrm{mM}$ ethanol failed to enhance the (approx. 4-fold) stimulatory effect of insulin on PI-3K activity after 5 min of incubation (results not shown).

Because branched-chain amino acids such as leucine regulate p70 S6 kinase activity [39] via the mammalian target of rapamycin (called mTOR, FRAP or RAFT), ethanol might modulate p70 S6 kinase activity by increasing amino acid uptake. However, 60-80 $\mathrm{mM}$ ethanol, examined in both the absence and the presence of $\mathrm{Zn}^{2+}$ and insulin, had no effect on the cellular uptake 


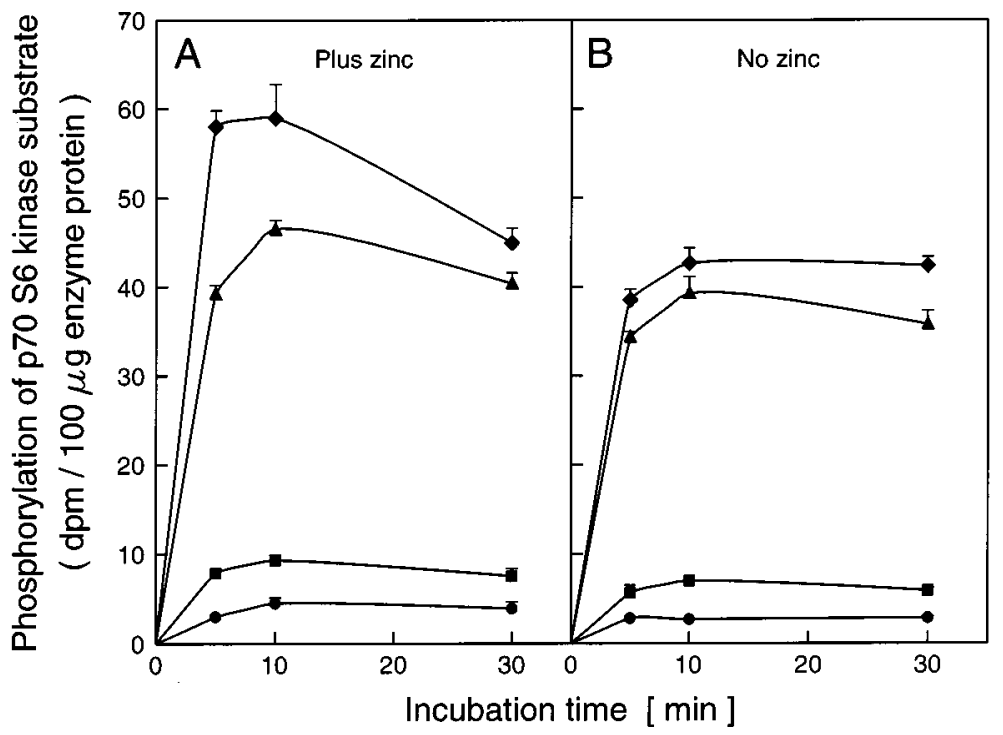

Figure 6 Combined effects of insulin, ethanol and $\mathrm{Zn}^{2+}$ on p70 S6 kinase activity

Serum-starved NIH 3T3 fibroblasts were first treated $(\mathbf{A})$ or not $(\mathbf{B})$ for 2 min with $40 \mu \mathrm{M} \mathrm{Zn}{ }^{2+}$, followed by 2 min of treatment with ethanol. The cells were then incubated for $5-30$ min in the absence $(\boldsymbol{O})$ or presence of $500 \mathrm{nM}$ insulin $(\boldsymbol{\Delta}), 60 \mathrm{mM}$ ethanol $(\boldsymbol{\square})$ or insulin plus ethanol $(\boldsymbol{})$. Points are averages of two independent incubations; the error bars indicate the differences between the values. The 10 min time point was repeated three times with similar results.

of radiolabelled leucine and glutamine over an $8 \mathrm{~h}$ period (results not shown).

\section{DISCUSSION}

Although ethanol in itself is not a carcinogen or mutagen, it can be a risk factor for certain cancers [10-15]. Of the various possible mechanisms that might explain the tumour-promoter character of ethanol action, the direct stimulation of DNA synthesis is a likely candidate $[17,18]$. One possibility is that ethanol stimulates DNA synthesis before damaged DNA is completely repaired. This could enhance carcinogen-induced structural alterations in the DNA, particularly at mutational (oncogenic) hotspots where repair seems to be slow [40]. Furthermore, in certain cell types ethanol can also enhance cell proliferation [20], which might further promote the stabilization of these genetic changes. Because of these implications, an important goal in our research is to understand the mechanism by which ethanol can promote DNA synthesis.

Previously we found that in NIH 3T3 fibroblasts and several other cell lines ethanol can increase the effects of insulin and IGF-I on DNA synthesis by a $\mathrm{Zn}^{2+}$-dependent mechanism [17-19]. The effects of ethanol were observed in a concentration range $(30-60 \mathrm{mM})$ that is often attained in subjects who abuse alcohol [41,42]. The requirement for $\mathrm{Zn}^{2+}$ is important because although $\mathrm{Zn}^{2+}$ is an essential micronutrient [43], it is absent from most cell culture media including DMEM.

Now we have found that ethanol, $\mathrm{Zn}^{2+}$ and insulin can each be best described as progression factors, because in serum-starved fibroblasts their synergistic actions require either brief pretreatments with growth factors or the presence of a relatively large concentration of extracellular $\mathrm{Ca}^{2+}$ to initiate the cell cycle. Because the continuous presence of $\mathrm{Ca}^{2+}$ was still required for the maximal combined actions of ethanol, $\mathrm{Zn}^{2+}$ and insulin even after growth factor treatments, it seems that $\mathrm{Ca}^{2+}$ has important functions both in the initiation process and in the maintenance of the cell cycle. This agrees well with earlier observations that $\mathrm{Ca}^{2+}$ is required for practically all stages of the cell cycle [26].

The combined effects of ethanol, $\mathrm{Zn}^{2+}$ and insulin on cell cycle progression became detectable between 1.1 and $1.5 \mathrm{mM} \mathrm{Ca}^{2+}$. This would suggest that only very modest or no promitogenic ethanol effects can occur in vivo despite the presence of $\mathrm{Zn}^{2+}$, insulin/IGF-I and cell-cycle-initiating growth factors in the circulation because the concentration of ionized $\mathrm{Ca}^{2+}$ in the blood is estimated to be in the range $1.0-1.2 \mathrm{mM}$. However, numerous extracellular compartments exist, including the dermal layer of the skin [44], that can undergo substantial increases in $\mathrm{Ca}^{2+}$ concentration [45]. Thus although it is reasonable to assume that the promitogenic effects of ethanol can occur in vivo, it is likely that the concentration of extracellular $\mathrm{Ca}^{2+}$ in a given tissue at a given time limits the action of ethanol.

Although it was not in the focus of the present investigation, we noted that in the presence of $2.8-3.3 \mathrm{mM} \mathrm{Ca}^{2+}, \mathrm{Zn}^{2+}$ alone substantially increased DNA synthesis. This suggests that in the dermal layer of skin (because of the high $\mathrm{Ca}^{2+}$ concentration) $\mathrm{Zn}^{2+}$ might be a mitogen in vivo. Such a mechanism, which remains to be proved, might contribute to the well-known positive effects of $\mathrm{Zn}^{2+}$ on skin regeneration [43].

The evidence presented here suggests that the promoting effects of ethanol on DNA synthesis in serum-starved fibroblasts are not mediated by the $\mathrm{Ca}^{2+}$ receptor. However, the promitogenic effects of ethanol are clearly sensitive to neomycin, a relatively non-specific agent, which might provide some help in the further delineation of the actions of ethanol. One possible way of explaining the interactions between ethanol and $\mathrm{Ca}^{2+}$ is that, in the presence of ethanol and $\mathrm{Zn}^{2+}$, less $\mathrm{Ca}^{2+}$ stimulation is sufficient to achieve increased DNA synthesis by the combined actions of $\mathrm{Ca}^{2+}$ and insulin. Alternatively, the promitogenic effects of ethanol might be mediated by $\mathrm{Ca}^{2+}$, a mechanism that is supported by the observed stimulatory effect of ethanol on $\mathrm{Ca}^{2+}$ uptake. However, more experiments will be required to prove the role of either mechanism. 
Because the activation of $\mathrm{p} 42 / \mathrm{p} 44$ MAP kinases is required for cell cycle progression through $\mathrm{G}_{1}$ and S-phase, the ability of $\mathrm{Zn}^{2+}$ to prevent the inhibitory effects of ethanol on insulin-induced activating phosphorylation of MAP kinases might explain, at least in part, why the promitogenic ethanol effects depend on $\mathrm{Zn}^{2+}$. However, because in the presence of $\mathrm{Zn}^{2+}$ ethanol did not increase MAP kinase phosphorylation or activation, it is clear that there has to be one or more other mechanisms, $\mathrm{Zn}^{2+}$ dependent or $\mathrm{Zn}^{2+}$-independent, that actually mediate the promitogenic effects of ethanol.

Insulin activates p70 S6 kinase both in the cytosolic and nuclear compartments [46]. The activation of p70 S6 kinase in the smaller nuclear pool is maximal after $5 \mathrm{~min}$ of treatment and declines after $10 \mathrm{~min}$, whereas in the larger cytosolic pool the enzyme is maximally activated after $10 \mathrm{~min}$ of treatment, with little decline during a subsequent $20 \mathrm{~min}$ period [46]. Ethanol transiently increased the effect of insulin on p70 S6 kinase activation by a $\mathrm{Zn}^{2+}$-dependent and apparently PI-3K-independent mechanism. In view of the profile of insulin action and the time course of the effect of ethanol (Figure 6), ethanol might specifically enhance the insulin-induced activation of the smaller nuclear pool of p70 S6 kinase. Regardless of the mechanism of the ethanol effect, increased p70 S6 kinase activity might contribute to the mediation of promitogenic ethanol actions.

In summary, we have shown that in serum-starved NIH 3T3 fibroblasts a single addition of physiologically relevant concentrations of ethanol evokes progression-factor-like effects, resulting in a greater stimulation of DNA synthesis by insulin and IGF-I. The promitogenic effects of ethanol also require $\mathrm{Zn}^{2+}$ and initiation of the cell cycle by $\mathrm{Ca}^{2+}$ or growth factors. Further studies are required to determine how the promitogenic effects of ethanol might relate to its promoting effects on certain human cancers.

This work was supported by NIH Grant AA09292, by the Hormel Foundation and by SOTA TEC Fund 343-6027.

\section{REFERENCES}

1 Luo, J. and Miller, M. W. (1998) Brain Res. Rev. 770, 139-150

2 Cui, S. J., Tewar, M., Schneider, T. and Rubin, R. (1997) Alcohol. Clin. Exp. Res. 21, $1121-1127$

3 Bhave, S. V. and Hoffman, P. L. (1997) J. Neurochem. 68, 578-586

4 West, J. R., Chen, W. J. A. and Pantazis, N. J. (1994) Metabol. Brain Disease 9, 291-322

5 Eckardt, M. J., File, S. E., Gessa, G. L., Grant, K. A., Guerri, C., Hoffman, P. L., Kalant, H., Koob, G. F., Li, T.-K. and Tabakoff, B. (1998) Alcohol. Clin. Exp. Res. 22 998-1040

6 Franceschi, S., Talamini, R., Barra, S., Baron, A. E., Negri, E., Bidoli, E., Serraino, D. and La Vecchia, C. (1990) Cancer Res. 50, 6502-6507

7 Nachiappan, V., Mufti, S. I. and Eskelson, C. D. (1993) Nutr. Cancer 20, 293-302

8 Schuller, H. M., Jorquera, R., Reichert, A. and Castonguay, A. (1993) Cancer Res. 53, 2498-2501

9 Anderson, L. M., Carter, J. P., Driver, C. L., Logsdon, D. L., Kovatch, R. M. and GinerSorolla, A. (1993) Cancer Lett. 68, 61-66
10 Mirvish, S. S., Weisenburger, D. D., Hinrichs, S. H., Nickols, J. and Hinman, C. (1994) Carcinogenesis 15, 883-887

11 Harty, L. C. Caporaso, N. E., Hayes, R. B., Winn, D. M., Bravo-Otero, E., Blot, W. J., Kleinmann, D. V., Brown, L. M., Armenian, H. K., Fraumeni, Jr, J. F. and Shields, P. G. (1997) J. Natl. Cancer Inst. 89, 1698-1705

12 Leach, R. E., Stachecki, J. J. and Armant, D. R. (1993) Teratology 47, 57-64

13 Stachecki, J. J., Yelian, F. D., Schultz, J. F., Leach, R. E. and Armant, D. R. (1994) Biol. Reprod. 50, 1-9

14 Miller, M. W. (1996) Alcohol. Clin. Exp. Res. 20, 139-144

15 Kennedy, L. A. and Mukerji, S. (1986) Neurobehav. Toxicol. Teratol. 8, 17-21

16 Simanowski, U. A., Stickel, F., Maier, H., Gartner, U. and Seitz, H. K. (1995) Alcohol 12, 111-115

17 Kiss, Z., Anderson, W. H. and Mukherjee, J. J. (1998) Biochem. J. 330, 819-826

18 Mukherjee, J. J., Huang, J.-S., Getman, C. and Kiss, Z. (1999) Arch. Biochem. Biophys. 362, 183-189

19 Tomono, M. and Kiss, Z. (1995) Biochem. Biophys. Res. Commun. 208, 63-67

20 Crilly, K. S., Li, J., Anderson, W. H. and Kiss, Z. (1999) Alcohol. Clin. Exp. Res. 23 785-790

21 Giorgino, F., Belfiore, A., Milazzo, G., Costantino, A., Maddux, B., Whittaker, J., Goldfine, I. D. and Vigneri, R. (1991) Mol. Endocrinol. 5, 452-459

22 Frittitta, L., Vigneri, R., Stampfer, M. R. and Goldfine, I. D. (1995) J. Cell. Biochem. 57, 666-669

23 Blakesley, V. A., Kalebic, T., Helman, L. J., Stannard, B., Faria, T. N., Roberts, Jr, C. T. and LeRoith, D. (1996) Endocrinology (Baltimore) 137, 410-417

24 Kaleko, M., Rutter, W. J. and Miller, A. D. (1990) Mol. Cell. Biol. 10, 464-473

25 Schoen, R. E., Tangen, C. M., Kuller, L. H., Burke, G. L., Cushman, M., Tracy, R. P., Dobs, A. and Savage, P. J. (1999) J. Natl. Cancer Inst. 91, 1147-1154

26 Santella, L. (1998) Biochem. Biophys. Res. Commun. 244, 317-324

27 Kiss, Z. and Anderson, W. H. (1994) Biochem. J. 300, 751-756

28 Chung, T., Crilly, K. S., Anderson, W. H., Mukherjee, J. J. and Kiss, Z. (1997) J. Biol. Chem. 272, 3064-3072

29 Arora, P. D., Ma, J., Min, W., Cruz, T. and McCulloch, C. A. G. (1995) J. Biol. Chem. 270, 6042-6049

30 Grynkiewicz, G., Poenie, M. and Tsien, R. Y. (1985) J. Biol. Chem. 260, 3440-3450

31 Brown, E. M., Gamba, G., Riccardi, D., Lombardi, M., Butters, R., Kifor, O., Sun, A., Hediger, M. A., Lytton, J. and Hebert, S. C. (1993) Nature (London) 366, 575-580

32 Kifor, O., Diaz, R., Butters, R., Kifor, I. and Brown, E. M. (1998) J. Biol. Chem. 273, 21708-21713

33 Ruat, M., Snowman, A. M., Hester, L. D. and Snyder, S. H. (1996) J. Biol. Chem. 271, 5972-5975

34 McNeil, S. E., Hobson, S. A., Nipper, V. and Rodland, K. D. (1998) J. Biol. Chem. 273, 1114-1120

35 Pagès, G., Lenormand, P., L'Allemain, G., Chambard, J. C., Meloche, S. and Pouysségur, J. (1993) Proc. Natl. Acad. Sci. U.S.A. 90, 8319-8323

36 Chung, J., Grammer, T. C., Lemon, K. P., Kazlauskas, A. and Blenis, J. (1994) Nature (London) 370, 71-75

37 Lane, H. A., Fernandez, A., Lamb, N. J. C. and Thomas, G. (1993) Nature (London) 363, 170-172

38 Reinhard, C., Fernandez, A., Lamb, N. J. C. and Thomas, G. (1994) EMBO J. 13 $1557-1565$

39 Hara, K., Yonezawa, K., Weng, Q.-P., Kozlowski, M. T., Belham, C. and Avruch, J. (1998) J. Biol. Chem. 273, 14484-14494

40 Matton, N., Simonetti, J. and Williams, K. (1999) Oncogene 20, 1417-1424

41 Urso, T., Gavaler, J. S. and Van Thiel, D. H. (1981) Life Sci. 28, 1053-1056

42 Lands, W. E. M. (1998) Alcohol 15, 147-160

43 Vallee, B. L. and Falchuk, K. H. (1993) Physiol. Rev. 73, 79-118

44 Malmqvist, K. G., Carlsson, L. E., Forslind, B., Roomans, G. M. and Alselsson, K. R. (1984) Nucl. Instrum. Methods Phys. Res. B 3, 611-617

45 Brown, E. M., Vassilev, P. M. and Hebert, S. C. (1995) Cell 83, 679-682

46 Kim, S.-J. and Kahn, C. R. (1997) Biochem. Biophys. Res. Commun. 234, 681-685

Received 18 August 1999/5 November 1999; accepted 6 December 1999 